\title{
Analyzing Students' Errors in Solving Sequence and Series Application Problems Using Newman Procedure
}

\author{
Nur Agustiani \\ Universitas Muhammadiyah Sukabumi, Jl. R. Syamsudin, SH No. 50, Sukabumi, Indonesia \\ e-mail: nuragustiani@ummi.ac.id
}

\begin{abstract}
This study aims to analyze the errors of students in solving the problem of applying sequence and series based on Newman's rules. This research uses descriptive analysis method. The subjects of this study were first semester students majoring in business administration at Muhammadiyah University of Sukabumi. The data collection used test and interview methods. Based on the results of data analysis using the Newman error analysis procedure, it is concluded that students made $8.9 \%$ reading errors, $18.9 \%$ comprehension errors, $32.2 \%$ transformation errors, $42.2 \%$ process skills errors, and $43.3 \%$ encoding errors. The percentage of reading errors up to encoding errors has increased because students cannot solve the problem correctly after encountering obstacles at the beginning. Error analysis can be used as reference material for lecturers in designing learning that can overcome student errors in working on the applied of sequence and series.
\end{abstract}

Keywords: Newmann error analysis, problem-solving, sequence and series

How to Cite: Agustiani, N. (2021). Analyzing Students' Errors in Solving Sequence and Series Application Problems Using Newman Procedure. International Journal on Emerging Mathematics Education, 5(1), 23-32. http://dx.doi.org/10.12928/ijeme.v5i1.17377

\section{INTRODUCTION}

Sequence and series are one of the subjects in the business mathematics course. It is also one of the subject matters of mathematics in junior and senior high school. Although there are a few additions to the material of sequence and series in business mathematics courses, basically, students only need to remember and repeat what they learned previously in high school. Given that sequence and series have been learned at school, students should be more receptive to learning and solve problems given. However, most students tend to forget the material that has been studied previously. As a result, students still find it difficult and make mistakes when completing the questions given, especially in the form of its application. This can be seen from the results of the previous exams, only $20 \%$ of all students who scored above 80 .

Errors were found both in multiple-choice questions and essays. The most frequent mistake is made when solving applied problems in the form of story problems. Students tend to have more difficulty solving story problems than problems that only contain numbers (Susanti, 2017). In solving story problems, students must read to understand the purpose of the problems, then transform it into mathematical form. After transforming, students can solve it by choosing the right operation, then get the result and conclusion.

The existence of an error when solving the problems shows that there needs an ability to understand the story, choose and use the right formula, and make accurate calculations. These mistakes need to be studied and followed up to obtain more optimal learning outcomes. It is necessary to identify student errors in solving problems so that their learning outcomes are improved and then find solutions to solve them (Amir, 2015). 
Identification of students' errors in solving problems can be done by analyzing errors in the answers. Error analysis can be used to look deeply into the mistakes made by students in working on given problems (Kingsdorf \& Krawec, 2014). The results of the analysis can be used as a reference to improve the quality of learning in the classroom. So, it can help students in solving problems and also improve their learning outcomes. Furthermore, error analysis can be used as a consideration for developing learning models to improve problem-solving skills (Ningsih, 2017).

One procedure that can be used to analyze errors is Newman's Error Analysis (NEA). NEA was developed to assist teachers when facing students who have difficulty translating mathematical language. NEA can be used by teachers to develop better learning programs and make a good connection between literacy and numeracy (White, 2010).

There are five procedures in Newman's error analysis, reading, comprehension, transformation, process skills, and encoding (White, 2010). At the reading stage, students read the questions given. Stages of understanding, students understand the purpose of the problem. The stages of transformation, make a mathematical model, and choose the right formula. Next, at the process skill stage, students complete the answer by calculating it precisely. Finally, in the stage of encoding, students can give the correct answer and the conclusion. The findings of this research could be a benchmark analysis of the similar works to gain a better understanding of the students' erros in problem-solving, as well as inspiring a further action on how to solve it.

\section{RESEARCH METHOD}

This research uses the descriptive analysis method. This study aims to get an indepth overview and detailed information about student error in solving the problem of applying sequence and series based on Newman's error analysis stage. The subjects of this study were first-semester Business Administration students at Muhammadiyah University of Sukabumi.

Data collection techniques used in this study were test and interview methods. The test given consisted of 6 questions about the story of the sequence and series. The questions used are presented in Table 1.

Table 1. The test instrument

\begin{tabular}{cl}
\hline Number & \multicolumn{1}{c}{ Question } \\
\hline 1 & A cake seller sells one cheesecake pan for IDR 700,000. If he drops \\
& the price by IDR 10,000 per hour, specify: \\
a. the price of one cheesecake pan at 10 hours later, \\
b. the total money he gets if he sells 12 cheesecake after 10 hours. \\
The price of the latest laptop in 2020 is twenty-three million \\
rupiahs. If the price always decreases by $2 \%$ every year, how much \\
will the laptop cost in 2025? \\
Irma invested IDR 30,000,000 in the bank for 8 years. If the annual \\
interest rate is 9\%, determine: \\
a. total interest earned, \\
b. the amount of money that Irma will earn. \\
Kamal joins a student savings program with a compound interest of \\
12\% / year. If he keeps IDR 10,000 / week and keeps it for 4 years, \\
how much money will he get in the next 4 years?
\end{tabular}

IJEME, Vol. 5, No. 1, March 2021, 23-32. 


\begin{tabular}{|c|c|}
\hline Number & Question \\
\hline 5 & $\begin{array}{l}\text { A student plans to study abroad and he plans to save up to four } \\
\text { hundred million rupiahs in the bank. How much money should be } \\
\text { saved each week for } 5 \text { years, if the compound interest is } 4.2 \% \text { per } \\
\text { annum? }\end{array}$ \\
\hline 6 & $\begin{array}{l}\text { Rama will buy a house for two hundred and fifty million rupiahs in } \\
\text { installments for } 8 \text { years. If the interest is } 12 \% \text { per annum, } \\
\text { determine: } \\
\text { a. large installments each month. } \\
\text { b. the amount of money to be paid during the installment. }\end{array}$ \\
\hline
\end{tabular}

The data obtained in this study is the student answer sheet. The student answer sheet will be used to identify student's errors and determine the percentage of the types of student's errors in the sequence and series questions.

Data analysis was done by analyzing the error of the test results based on Newman's error analysis. Next, a reduction was made in the results of the tests to obtain conclusions that were used to describe the errors of students in solving the story problems in the application of sequence and series based on the NEA procedure.

\section{RESULTS AND DISCUSSION}

Based on the analysis of student answer sheets, it was found that the types of errors made by students were based on the Newman's procedure, namely reading errors, comprehension errors, transformation errors, process skill errors, and encoding errors. Table 2 presents the results of the recapitulation of errors made by students in solving questions about the implementation of sequence and series based on Newman's procedure.

Table 2. Percentage of students' errors based on Newman's error analysis

\begin{tabular}{cccccc}
\hline $\begin{array}{c}\text { Question } \\
\text { Number }\end{array}$ & $\begin{array}{c}\text { Reading } \\
\text { Error }\end{array}$ & $\begin{array}{c}\text { Comprehension } \\
\text { Error }\end{array}$ & $\begin{array}{c}\text { Transformation } \\
\text { Error }\end{array}$ & $\begin{array}{c}\text { Process Skill } \\
\text { Error }\end{array}$ & $\begin{array}{c}\text { Encoding } \\
\text { Error }\end{array}$ \\
\hline 1 & $6.7 \%$ & $20.0 \%$ & $40.0 \%$ & $53.3 \%$ & $53.3 \%$ \\
2 & $6.7 \%$ & $13.3 \%$ & $40.0 \%$ & $46.7 \%$ & 46.67 \\
3 & $6.7 \%$ & $6.7 \%$ & $6.7 \%$ & $13.3 \%$ & $13.3 \%$ \\
4 & $6.7 \%$ & $33.3 \%$ & $53.3 \%$ & $53.3 \%$ & $60.0 \%$ \\
5 & $13.3 \%$ & $26.7 \%$ & $33.3 \%$ & $53.3 \%$ & $53.3 \%$ \\
6 & $13.3 \%$ & $13.3 \%$ & $20.0 \%$ & $33.3 \%$ & $33.3 \%$ \\
Average & $8.9 \%$ & $18.9 \%$ & $32.2 \%$ & $42.2 \%$ & $43.3 \%$ \\
\hline
\end{tabular}

Table 2 shows that the percentage of reading errors up to the percentage of encoding errors has increased. This is because students cannot solve problems correctly if they have experienced problems at the beginning. The following discussion about each of the errors based on Newman's procedure.

\section{Reading error}

The results of data analysis showed that the average percentage of reading errors was $8.9 \%$. This shows that the reading error is fairly low. It is due to questions given using language commonly used in daily life and not using mathematical symbols that might not be recognized. Reading errors occur due to the inaccuracy of students 
in reading questions. Examples of reading errors are errors made by Subject 1 (S01) while working on question no 6. Examples of such errors can be seen in Figure 1.

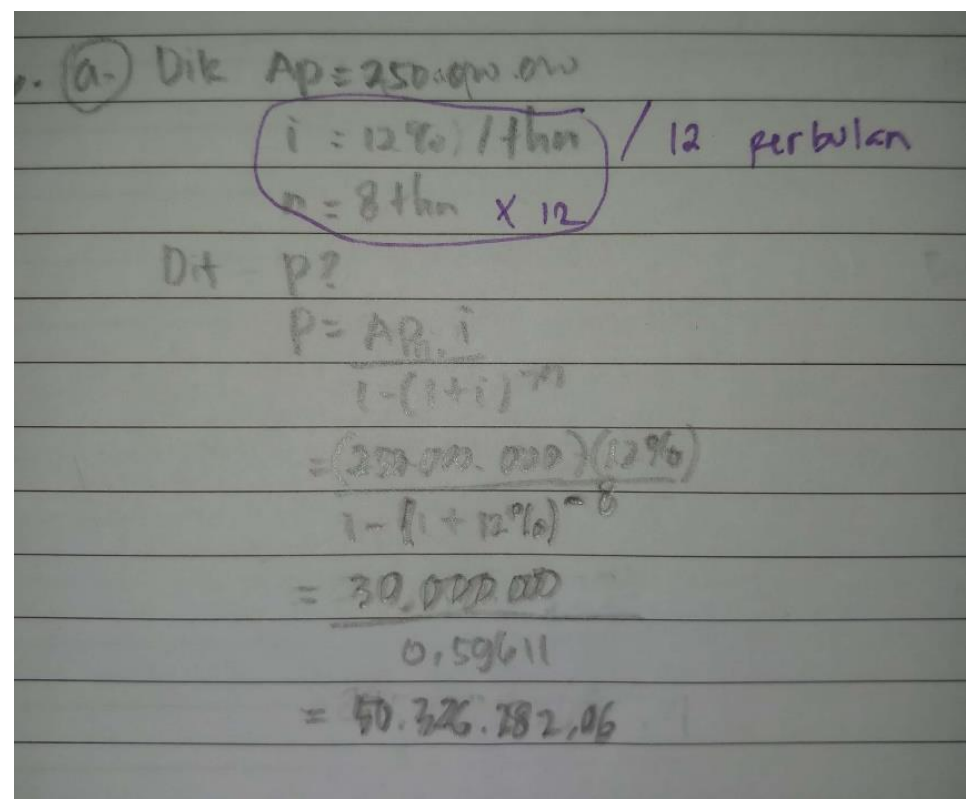

Figure 1. Sample work of S01 in question number 6

S01 made a reading error that is not reading information carefully. In the problem given, asked to determine the number of installments every month, but S01 calculates the number of installments every year. S01 performs the calculation process correctly, without changing the interest rate (i) per year to monthly and changing the period (n) into months. S01 does not read the keywords carefully in the problems needed for the process. At the time of the interview, S01 admitted that he was too focused on completion without paying close attention to the problem.

Reading error is very unlikely to occur as long as the language used is commonly used, does not mean double, and is easily understood. Reading errors occur when students cannot read keywords or symbols in a problem that hinders problem-solving (Jha, 2012).

\section{Comprehension error}

The percentage of comprehension error was $18.9 \%$, it was greater than reading errors. Although students can read the questions correctly, some students do not understand the meaning of the problem so they cannot solve the problem. Comprehension error occurs when the student does not understand the overall meaning so he can not solve the problem, even though he has been read correctly (Jha, 2012). Comprehension Error is marked by there is not information written in the solution. This can be shown by not writing what is known and what is asked in the problem. (Rahmawati \& Permata, 2018). Figure 2 is an example of a comprehension error.

Subject 2 (S02) wrote inaccurate information. He did not write down the annual decrease namely $2 \%$, and did not write a model for the geometric sequence but wrote for the arithmetic sequence. When interviewed, he mentioned that he interpreted the decrease as a consistent price reduction every year, so he wrote a model for the

IJEME, Vol. 5, No. 1, March 2021, 23-32. 
arithmetic sequence. He said that he did not understand the problem so he solved the problem with his interpretation.

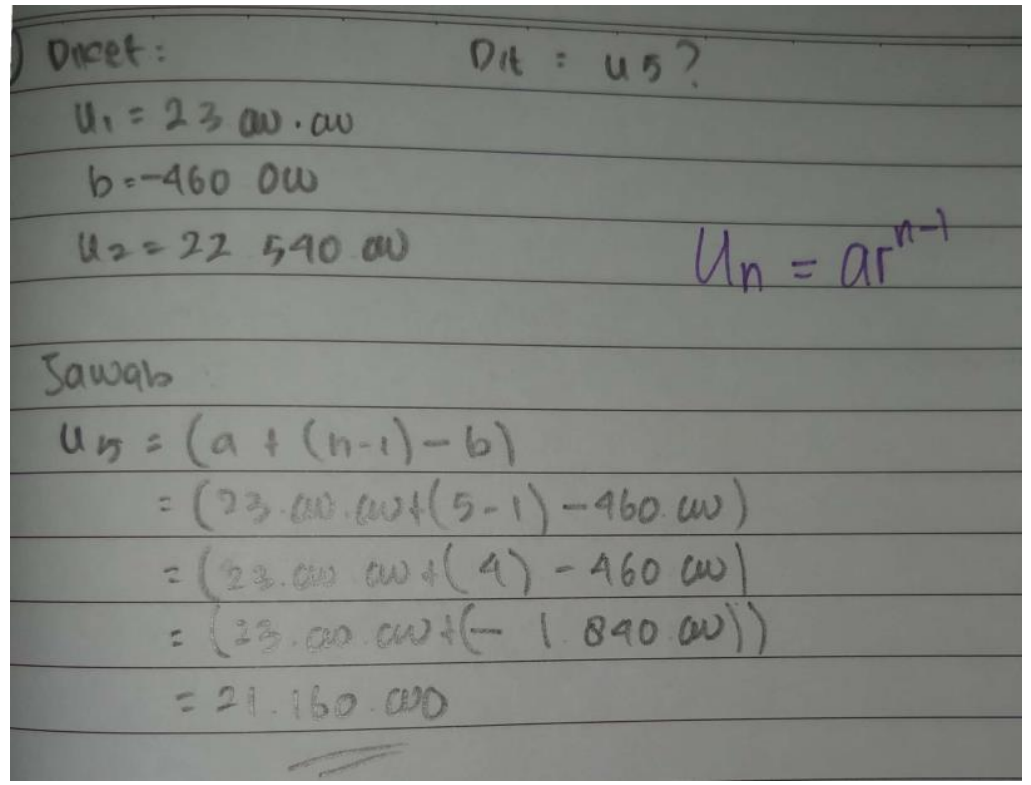

Figure 2. Sample work of S02 in question number 2

Another error is shown in Figure 3, where subject 3 (S03) made a mistake in question no.5, namely not writing down information clearly, just rewriting some of the information and questions. S03 also solved the problem without any meaning, only reducing the estimated cost by the product of the estimated cost with the interest rate. When confirmed, he did not understand the purpose of the problem so he only tried to operate without knowing the meaning.

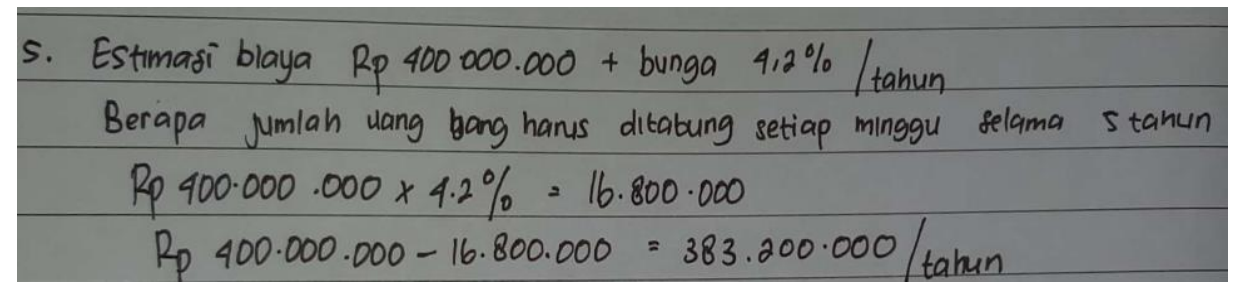

Figure 3. Sample work of S03 in question number 5

\section{Transformation error}

The transformation errors are shown when students cannot identify the operation or part of the operation that will be used in solving the problem (Jha, 2012). The formula to be used is not written correctly is also a transformation error (Chusnul et al., 2017). In the results of data analysis, the average percentage of transformation errors is $32.2 \%$, it means that it is greater than reading error and comprehension error. This is because some students who understand the meaning of the problem could not make a model in mathematical form or did not know the formula. 


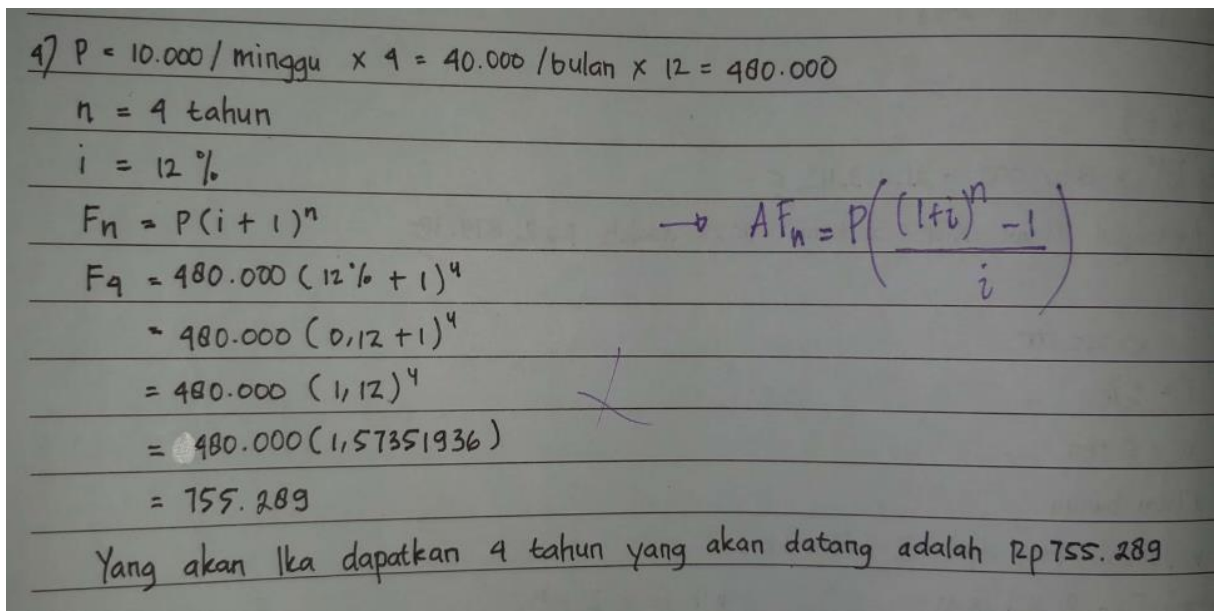

Figure 4. Sample work of S04 in question number 4

Transformation error made by subject 4 (S04) is not writing the right formula to solve the problem. Based on his interview, he forgot which formula to use, so he wrote down the formula that he remembered without knowing it was right or wrong.

Besides cases like S04, where students write incorrect formulas, some students use the correct formula but didn't write the formula correctly. As seen in Figure 5, Subject 5 (S05) writes $(1+i)^{n}$ where it should be $(1+i)^{-n}$. He said that he understood the purpose of the problem and knew which formula should be used to solve it, but he was not careful and forgot the negative sign. Transformation error can occur when students understand the problem, but cannot succeed in developing an appropriate operation to solve the problem (Prakitipong \& Nakamura, 2006).

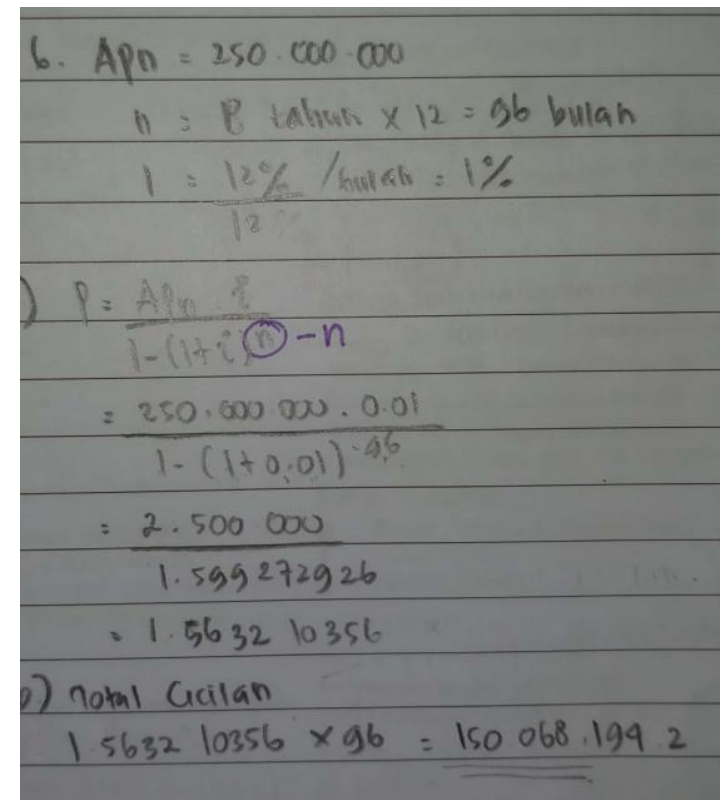

Figure 5. Sample work of S05 in question number 6

\section{Process skill error}

Process skills error is shown when students cannot do the steps of the operation correctly (Jha, 2012). Process skills error has seen after selecting and writing the formula correctly, but carrying out its operations isn't correct (Chusnul et al., 2017). In 
data analysis, the average percentage of process skill errors was $42.2 \%$. This shows that there are students who reach the transformation stage do not make mistakes but are not careful in their calculation process.

Examples of process skill errors are shown in Figure 6, where Subject 6 (S06) made a mistake when working on question number 1 . He was wrong in the process of solving, where should the problem of decrease, the difference in the sequence is negative. It turned out that after being confirmed to S06, he felt had done it right, but he was not careful enough. He forgets the keyword in the problem that he has written.

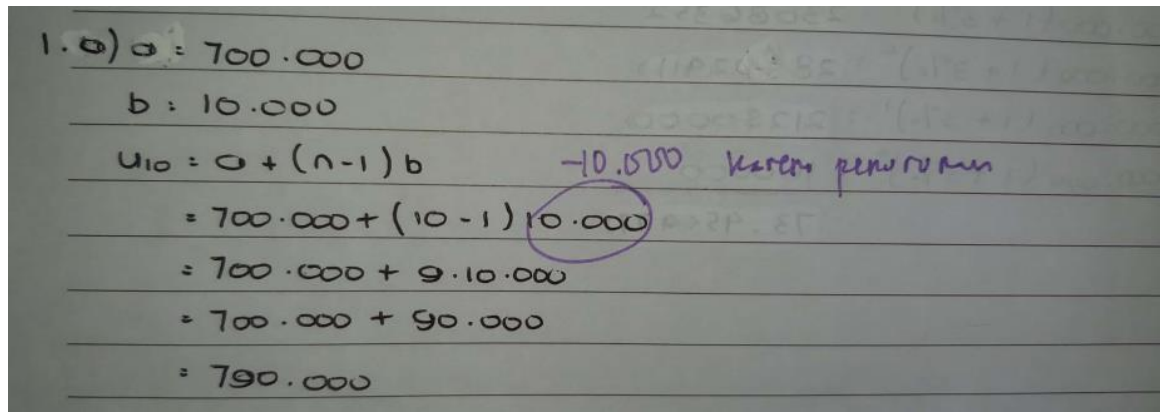

Figure 6. Sample work of S06 in question number 1

Examples of other process skill errors are shown in Figure 7. Subject 7 (S07) made a calculation error from the beginning. After being interviewed, S07 said that he felt confused in the divided of percentages so that even though he understood the problem and knew the formula to be used, he found obstacles in carrying out the calculation process.

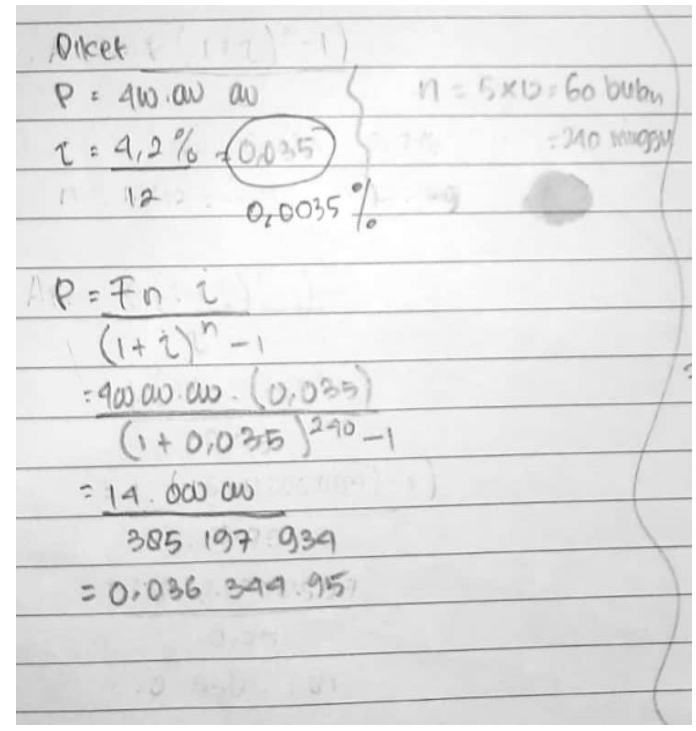

Figure 7. Sample work of S07 in question number 5

\section{Encoding error}

The percentage of encoding error is not much different from the process skill error, which is $43.3 \%$. This is because when a student is wrong in the process he cannot find the right result. Also, when from the beginning students did not understand the purpose of the problem, they could not write the right conclusions. 
Encoding error is shown when students can not express solutions (Jha, 2012). It can be said, the encoding error was found after reaching the data processing stage but failed in writing the final solution (Santoso et al., 2017). Figure 8 is an example of an encoding error.

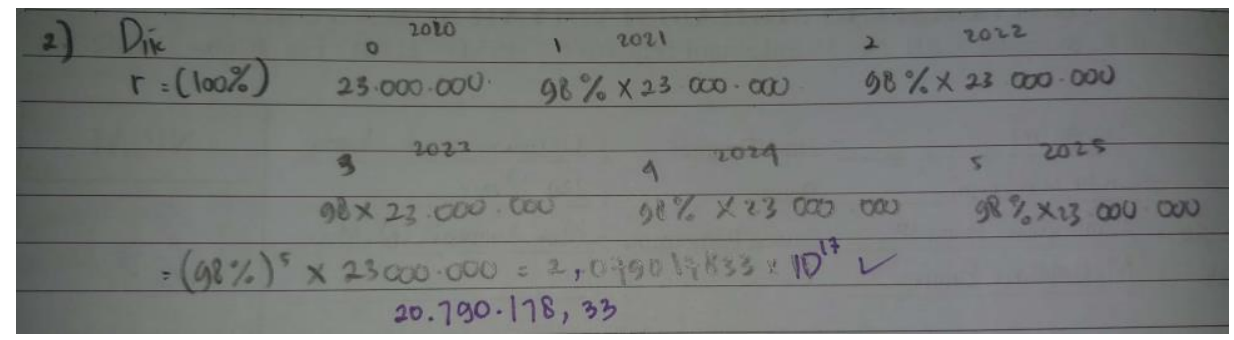

Figure 8. Sample work of S08 in question number 2

Subject 8 (S08) wrote the final result that was not quite right. After the interview, it turns out that S08 felt confused in changing the decimal form into rank 10. So S08 did not feel confident with the final results he wrote.

\section{CONCLUSION}

Based on the results of data analysis using the Newman error analysis procedure, the percentage of the students making reading errors is $8.9 \%$, comprehension errors is $18.9 \%$, transformation errors is $32.2 \%$, process skills errors is $42.2 \%$, encoding errors is $43.3 \%$. The reading error found was students who did not read the information in the question completely. The comprehension error found was that the student wrote the wrong information and did not write down the information needed. The transformation error found was that the student used an incorrect formula or did not write the formula correctly. Process skills error found was students making concept errors and doing wrong calculations. The encoding error found was student cannot find the result correctly. Error analysis in working on the application of sequence and series can be used by students as a reflective so that they can read and understand questions correctly, model problems in mathematical form, do calculations correctly, and get appropriate answers. It also can be used as a reference for lecturers to design learning that can overcome student errors in working on the application of sequence and series.

\section{REFERENCES}

Amir, M. F. (2015). Analisis Kesalahan Mahasiswa PGSD Universitas Muhammadiyah Sidoharjo dalam Menyelesaikan Soal Pertidaksamaan Linier. Jurnal Edukasi, 1(2), 131-146.

Chusnul, Rr. C., Mardiyana, \& Retno, D. S. (2017). Errors Analysis of Problem Solving Using the Newman Stage After Applying Cooperative Learning of TTW Type. AIP Conference Proceedings, 1913, 020028-1-020028-7.

Jha, K. S. (2012). Mathematics Performance of Primary School Students in Assam (India): An Analysis Using Newman Procedure. International Journal of Computer Application in Engineering Sciences, 2(1), 17-21.

Kingsdorf, S., \& Krawec, J. (2014). Error Analysis of Mathematical Word Problem Solving Across Students with and without Learning Disabilities. Learning Disabilities Research \& Practice, 29(2), 66-74. 
Ningsih, S. C. (2017). Meningkatkan Kemampuan Pemecahan Masalah Mahasiswa Pendidikan Matematika UPY Pada Mata Kuliah Teori Bilangan Melalui Model Pembelajaran Creative Problem Solving (CPS) Siska. Mercumatika, 1(2), 132138.

Prakitipong, N. \& Nakamura, S. (2006). Analysis of Mathematics Performence of Grade Five Students in Thailand Using Newman Procedure. Journal of International Cooperation in Education, 9(1), 111-122.

Rahmawati, D. \& Permata, L. D. (2018). Analisis Kesalahan Siswa dalam Menyelesaikan Soal Cerita Program Linear dengan Prosedur Newman. Jurnal Elektronik Pembelajaran Matematika, 5(2), 173-185.

Santoso, D. A., Farid, A. \& Ulum, B. (2017). Error Analysis of Students Working About Word Problem of Linear Program with NEA Procedure. Journal of Physics: Conference Series, 855, 012043.

Susanti. (2017). Analisis Kesalahan Siswa dalam Menyelesaikan Soal Cerita Program Linier Berdasarkan Tahapan Newman. Jurnal Ilmiah Pendidikan Matematika, 2(6), 71-76.

White, A. L. (2010). Numeracy, Literacy and Newman's Error Analysis. Journal of Science and Mathematics Education in Southeast Asia, 33(2), 129-148. 
This page is intentionally left blank.

IJEME, Vol. 5, No. 1, March 2021, 23-32. 